\title{
Public Services of North Aceh Sharia Bureau During Pandemic
}

\author{
Maryam $^{1, *}$ Ade Muana Husniati ${ }^{2}$ \\ ${ }^{1}$ Department of Public Administration, Universitas Malikussaleh \\ ${ }^{2}$ Department of Communication, Universitas Malikussaleh \\ *Email: maryammar@unimal.ac.id
}

\begin{abstract}
There has been an increase in the number of people suffering from Covid 19 in several provinces in Indonesia including Aceh. Based on data from the Aceh Covid Task Force as of October 2020, there are 173 people confirmed, 96 patients under treatment, 68 patients recovered and 9 people died. Due to the pandemic, both central and regional civil servants work from home adjusting to the new work system. Publis services in all sectors have changed, and so does the service provided by the North Aceh Syaria and Human Rights Bureau. The pandemic triggered the bureau to issue internal instruction for continuing the public service. Several programs undertaken were the enforcement of Islamic Syaria especially in undergoing canning punishment for those commit adultery, get drunk, and gamble. Based on the data obtained, there was no stopping of Islamic syaria implementation despite the pandemic. Raids and punishments were given following the health protocol. The service given was identical with the service to enforce the implementation of Islamic syaria while administration service is still at the level of implementing office routines.
\end{abstract}

Keywords: Public services, Aceh Sharia Bureau, Pandemic Covid-19

\section{INTRODUCTION}

Aceh is one of the regions in Indonesia that has special autonomy, which is a principle to handle government affairs based on duties, powers, and obligations in accordance with the potential and uniqueness of the region. Special autonomy is an affirmative step taken by the central government to increase development and equality between regions as well as to protect and guarantee the rights of minorities to be free from discrimination (Surya \& Saleh, 2017).

Aceh becomes special because of the existence of the sharia bureau. According to Lubis (2007), in its implementation, Islamic Shari'a has objectives that must be maintained for the benefit of mankind, preventing damage, and realizing the ultimate good. In North Aceh, particularly, the bureau attempts to realize the supremacy of Islamic law in the midst of society. Besides, they intend to serve people who need guidance and ishlah, to coordinate the functions of the Syar'iyah Court, the Attorney General's Office, the Police and the Regional Office of Justice as implementing institutions for Islamic Sharia through the judiciary, as well as to increase knowledge, understanding, and public awareness regarding Islamic law and sharia.

The spread of the corona virus has occurred in the last eight months due to SARS-CoV2 which has spread rapidly to several countries including Indonesia (PPT Puryono). The cases of covid19 have kept increasing in several provinces in Indonesia, including Aceh. Based on data from Aceh Covid Task Force as of October 2020, the number of COVID-19 patients in North Aceh was 173 confirmed, 96 under treatment, 68 patients recovered, and 9 died (Aceh Health Service data October 2020). Having observed such an increase, public services have changed completely; especially the way of the state apparatus provides services to the community. It has changed since March 2020 where both central and regional State Civil Apparatus work from home (WFH). The adjustments to the work system are carried out from the central agency to the regions. Public services in all sectors are automatically disrupted, including education, health services, land 
services, taxation, goods, and services. Likewise, North Aceh sharia and human rights bureau also issued internal instructions in carrying out public services in the field of Islamic law during the Covid period.

\section{PUBLIC SERVICES}

Albrecht Lovelock in Sedarmayanti (2007) defines service as a total organizational approach that becomes the quality of service received by users as the main driving force in business operations. Service means providing service needed by the community in all fields. Service to the community is one of the duties and functions of the State administration (Sedarmayanti, 2009). Service is efforts made by a person and/or group of people or certain institutions to provide assistance and convenience to the community in achieving goals (Thoha in Sedarmayanti, 2009).

Public services are closely related to the government because one of their responsibilities is to provide services to the community. The quality of public services can be used as a benchmark in assessing the quality of government services. According to Sinambela in Putra, et al (2020), public service is defined as giving interests to the organization in accordance with the basic rules and established procedures.

In order to ensure the quality of public services from all sectors, it is expected that government at all levels assess the satisfaction of given services through Law Number 25 of 2009 concerning public services. This act explains that public services are activities to fulfill needs in accordance with applicable laws, citizens, residents of goods, services, and / or administrative services provided by public service providers. This law regulates the principles of public service which are the prime service standards for all government services. The principles of public service are public interest, legal certainty, equal rights, the balance between rights and obligations, professionalism, participation, equality of treatment, openness, and accountability.

Nurcholis in Karhab (2013) considers public service as a number of people who have similar rights, thoughts, feelings, hopes, attitudes, and actions based on the values they have. According to the Decree of Ministry of Administrative and Bureaucratic Reform number 63 / KEP / M.PAN / 7/2003, public service is activities carried out by providers as an effort to meet the needs of service recipients and the implementation of statutory provisions.

\section{THE NATURE OF PUBLIC SERVICES}

Here are the characteristics of public services:

a. Improving the quality and productivity of duties and functions;

b. Encouraging efforts to streamline the system and service management so that public services can be carried out more efficiently and effectively;

c. Encouraging the creativity, initiative, and community participation in developing and improving the welfare of the wider community.

Public service is all forms of activities carried out by central and regional government, and within the State / Regional Owned Enterprises in the form of goods and services, both in the context of fulfilling community needs and in the framework of implementing statutory provisions. Public services must contain the following elements:

1. The rights and obligations of the providers and recipients of public services should be clear and certain;

2. The public services must be in accordance with the conditions of the needs and should be affordable;

3. Efforts must be made to ensure that the services are provided in order to provide security, comfort, smoothness, and justifiable to the legal certainty.

4. If public services provided by the government appear to be expensive, they should provide opportunities for the community to participate in organizing the service in accordance with statutory regulations (Sedarmayanti, 2009).

Public services should pay attention to these several factors:

a) Simplicity; procedures are carried out easily, smoothly, quickly, easy to understand, and easy to implement.

b) Clarity of certainty regarding the following matters:

1. Procedures for public services;

2. General service requirements, both technical and administrative;

3. Work units who are responsible for providing services;

4. Details of fees for public services and payment procedures;

5. Schedule of public service;

6. The rights and obligations of both the provider and recipient of public services based on evidence of receipt as a means of ensuring the processing of public services.

7. Officials receiving public complaints.

c) Security; processes and results of public services can provide security, comfort, and legal certainty;

d) Openness; procedures, requirements, work units of officials in charge of public services, schedule and details of costs and other matters related to the process must be informed openly so that public can easily understand; 
e) Efficient;

1. Requirements for services are limited to matters which are directly related to the achievement of service targets while still paying attention to the integration of requirements with the public service products provided.

2. It is prevented from repetition of the fulfillment of the requirements in terms of the process required from the work unit.

f) Economical; the public service fees must be reasonable by taking into account the following matters:

1. Value of public goods and/or services without demanding unreasonably high fees;

2. General condition and the affordability;

3. Applicable statutory provisions.

g) Equitable justice; coverage of public services must be endeavored to be as broad as possible with an even distribution.

h) Timeliness; the implementation of public services can be completed within a predetermined time (Decree of Ministry of Administrative and Bureaucratic Reform number 81/1993 (Sedarmayanti, 2009).

\section{METHODOLOGY}

Qualitative research is descriptive attempting to describe the relationship of causes and effects found in observations. Creswel (2010) mentions that this type of research is intended to obtain an overview related to Islamic law enforcement services in North Aceh. The data collection techniques used by researchers were (1) observation by directly observing the facts occurring at the research location; (2) Interview by meeting people to exchange information through question and answer so that meaning can be constructed in a particular topic; (3) Documentation to collect data or information from written documents, publications and official reports, personal diaries, letters, and photos. Data analysis was carried out interactively.

\section{PUBLIC SERVICES OF ACEH SHARIA BUREAU DURING THE COVID-19}

The services provided by the state apparatus are in the form of services needed by the community. In general, services at the Aceh Sharia Bureau are the same as services for other government agencies such as general administration services, personnel services, and financial services. During this pandemic, general services are still running by working from home following the Regent's instructions several months ago.
Up to now, the work is still being carried out at the office by prioritizing health protocols.

Types of services are closely related to the implementation of Islamic law such as routine studies on Tajhiz Mayit, the practice of managing mosques in villages in North Aceh, Tahfidz Houses and Islamic da'wah. Apart from these, the bureau has an Islamic Sharia enforcement program that is specifically carried out to punish the individuals or people who commit adultery, get drunk, and gamble. This is regulated in qanun number 6 of 2014 regarding qanun Jinayat, a criminal law based on the values of Islamic law applied to the Acehnese people who break the implementation of qanun.

Based on interviews, it shows that the caning (jinayat) law is carried out in order to reduce violations of Islamic law in North Aceh. To prevent people from committing the violations, the bureau carries out routine raids to places that have the potential to commit prohibited acts such as cafes. The raids are carried out by Wilayatul Hisbah (WH) and also the Civil Service Police Unit (SATPOLPP ). In addition, raising community's and youth's awareness about qanut jinayat and other qanun is also undertaken. Such programs are named as saweu sikula (coming to school for socialization), saweu gampong and saweu masjid (coming and socializing to mosques).

Furthermore, to serve people who need guidance and ishlah, the bureau coordinates the functions of the Syar'iyah Court, Attorney General's Office, the Police and the Regional Office of Justice as implementing institutions for Islamic Sharia through the judiciary by increasing knowledge, understanding, and public awareness of Islamic law and Islamic Sharia. They also supervise the implementation of Islamic Sharia through empowering Tuha Peuet, Tuha Lapan, Wilayatul Hisbah and encouraging and facilitating Qur'an recitation for children so that it runs well in all villages in North Aceh. During pandemic, the recitation system was carried out in groups with no more than 20 students and divided into small groups of 5 people per group.

To carry out health protocols, all employees are required to wear masks, keep their distance, wash their hands when they need to enter and leave the office. Service activities for official affairs are carried out by following health protocols. For urgent matters, the service employees will handle them directly while implementing the rules and regulations applied to the civil servants during the Covid period.

Based on interviews, it was found that there is no stopping of Islamic law implementation in the midst of the pandemic. There were cases of adultery and gambled in the month of Ramadan, and the officers still carry out duties while following the health protocol. When punishing those breaking the Islamic laws by canning, not many people came in order to avoid the crowd because the focus is to take precautions for violations of Islamic Sharia and provide awareness to the public. This implies that the Islamic law enforcement is still carried out during the pandemic 
while implementing health protocols. Routine raids were also carried out in conjunction with the socialization of the use of masks by $W H$ and SATPOLPP to prevent violations of Islamic law in North Aceh.

Research related to qanun jinayat by Berutu (2017) regarding inhibiting factors in the enforcement of qanun jinayat in Aceh ( a case study of implementation of qanun 14 of 2003 in Subulussalam) was carried out. The results of the study show that the factors underlying the ineffectiveness of the implementation of the jinayat qanun in Subulussalam concerning khalwat are both in terms of legal and non-legal factors. North Aceh sharia and human rights bureau also experienced several obstacles in implementing qanun jinayat.

The statement regarding the constraints in implementing Islamic Sharia is described in the results of the interview. There are some budget constraints from the local government as it requires a lot of money for data processing, staff, and data collection. However, obstacles to the implementation of prevention often arise from the perpetrators who sometimes rebel or do not accept the punishment.

From the interview, it can be seen that the services during the pandemic are identical to enforcement services for violations of sharia while general administrative services are still at the level of implementing normal routine in all offices. Besides, the constraints of budget provision by local governments are in the field of socialization and prevention of violations of Islamic law. There are pros and cons from the community regarding the punishment of canning which is considered as a disgrace and shame.

\section{CONCLUSION}

Public services at the bureau of North Aceh emphasize on the implementation of Islamic law enforcement, and the implementation is still carried out during the Covid-19 period of Ramadan. Matters related to the implementation of violations of Islamic law are coordinated and evaluated together with Wilayatul Hisbah, Satpol PP, and North Aceh MPU. In fact, the public services that should be provided are also those related to public services such as general administration services, staffing, information services and others.

\section{REFERENCES}

[1] Berutu A.g, Jurnal Faktor Penghambat dalam Penegakan Qanun Jinayat di Aceh (studi kasus penerapan Qanun nomor 14 tahun 2003 di Kota Subulussalam), 2017 (14), 148-169.

[2] Creswell, J, Research Design Pendekatan Kualitatif, Kuantitatif, dan Mixed, Yogyakarta, Pustaka Pelajar, 2013
[3] Karhab Rinda, Sandayani, Analisis Kinerja Pelayanan Publik PDAM tirta Kencana Kota Samarinda, Jurnal administrasi reform, 2013, 1 (2), pp 389-401

[4] Lubis, N.A.F The Child Rights In Islamic Law With A Spesial Focus On Aceh Jurnal Analisis Islamica, , 2007, 9 (2)

[5] Surya R \& Saleh, KA Relationship of Central and Local Government in Special Autonomy In West Papua, Jurnal Kajian Politik dan Masalah pembangunan, 2017, 13 (1), 1903-1919.

[6] Sedarmayanti, Good Governance (Kepemerintahan yang baik dan Good Coorporate Governance), Mandar Maju, 2007

[7] Sedarmayanti, Reformasi Administrasi Publik, Reformasi Birokrasi, dan Kepemimpinan Masa Depan (mewujudkan Pelayanan Prima dan Kepemerintahan Yang baik), Mandar Maju, 2009.

[8] Putra Amri Pratama, dkk, Studi Persepsi Masyarakat Atas Pelayanan E-Toll di Kota Makasar, Jurnal Analisis Kebijakan Publik dan Pelayanan Publik (JAKKP), 2020, 6 (1), pp 86-100

[9] Sri Puryono, (2020) Power Point (PPT) Diskusi Virtual Nasional Kebijakan dan Strategi Membangun Kehidupan (berbagai Sektor Melawan Covid 19).

[10] www.Dinkes.Acehprov.go.id diakses oktober 2020 